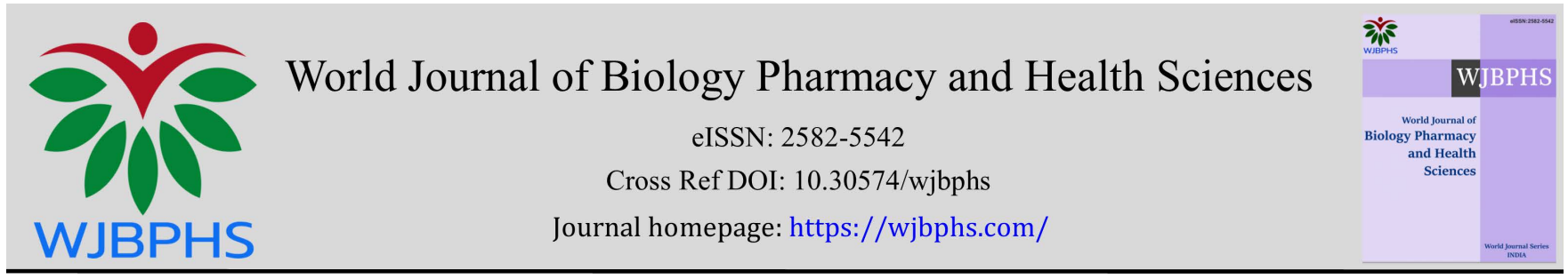

(REVIEW ARTICLE)

\title{
Ethnopharmacological review of traditional medicinal plants as immunomodulator
}

\author{
Ashvini Y. Parbat ${ }^{1}$, Gunjan P. Malode ${ }^{1}$, Aayesha R. Shaikh ${ }^{2}$, Wrushali A. Panchale ${ }^{1,}{ }^{*}$, Jagdish V. Manwar ${ }^{2}$ \\ and Ravindra L. Bakal ${ }^{1}$
}

${ }^{1}$ IBSS's Dr. Rajendra Gode Institute of Pharmacy, Amravati-444 602, MS, India.

${ }^{2}$ IBSS's Dr. Rajendra Gode College of Pharmacy, Amravati-444 602, MS, India.

World Journal of Biology Pharmacy and Health Sciences, 2021, 06(02), 043-055

Publication history: Received on 04 April 2021; revised on 10 May 2021; accepted on 12 May 2021

Article DOI: https://doi.org/10.30574/wjbphs.2021.6.2.0048

\begin{abstract}
Medicinal plants play significant roles in the prevention of human beings from various pathogenic microorganisms and diseases. The immunomodulators are agents used to modulate the immune system and can be obtained from both natural as well as synthetic origin from plants and chemicals. Alteration within the system is often achieved by immunomodulatory agents from a plant source, low molecular weight compounds like alkaloids and other nitrogencontaining compounds, terpenes, phenols, and high molecular weight compounds like lectins, polysaccharides. The Immune system is a part of the body to detect the pathogen by using a specific receptor to produce an immediate response by the activation of immune components cells, cytokines, and chemokines and also release of an inflammatory mediator. This review also discusses various ethnopharmacological information of traditional medicinal plants being used as immunomodulators.
\end{abstract}

Keywords: Medicinal plants; Immunomodulators; Immunostimulants; Immunoadjuvants.

\section{Introduction}

Today, worldwide a novel coronavirus disease (COVID-19) caused by Severe Acute Respiratory Syndrome Coronavirus 2 (SARS-CoV-2) has emerged as havoc to humanity. The disease has unfolded globally and caused more than three lakh casualties. Worldwide many efforts and measures have been taken by the countries to control this pandemic but it is ceaselessly spreading. Now the dimension of pandemic forces us to explore the available options present in all knowledge systems practicing globally [1,2]. A ray of hope has come from China wherever they used Traditional Chinese Medicine (TCM) to treat COVID-19 cases and to seek out better recovery results. This can also draw the attention of the scientific community to Ayurveda classics and their experimental knowledge to get explored for finding a cure for this pandemic [3].

Nowadays, the use of plants or parts thereof is being used worldwide, and in the COVID-19 situation, WHO recommending to use of herbal medicines for treatment or prophylactic use in the prevention of diseases or disorders. There are thousands of plants that are being used throughout the world as medicinal plants [4-10]. According to the World Health Organization, around $80 \%$ of the world population uses herbal medicines for primary health care, particularly across South Asia and Europe. Research studies indicate that along with building up the body's immunity, they also have anti-inflammatory properties and relatively have fewer side effects [11-12].

The System is one of the foremost complex biological systems within the body. At the time of infection, the immune system goes under the attack of a large number of viruses, bacteria, and fungi. Modulation of immune functions by utilizing medicinal plants and their products as a possible therapeutic measure has become an accepted therapeutic

* Corresponding author: Wrushali A. Panchale

IBSS's Dr. Rajendra Gode Institute of Pharmacy, Mardi Road, Amravati- 444602, MS, India.

Copyright (C) 2021 Author(s) retain the copyright of this article. This article is published under the terms of the Creative Commons Attribution License 4.0. 
approach. Plants and minerals have been used since ancient times for the treatment of many infirmities and diseases. It is now being that immunomodulation of immune response could provide an alternative to conventional chemotherapy for a variety of disease conditions, especially when the host's defense mechanism has to be activated under conditions of impaired immune responsiveness or when a Particular immunosuppressant has to be induced in a situation such as autoimmune disorders or organ transplantation. Immunity is a homeostatic process a series of finely balanced complex, multicellular and physiologic mechanisms that allow an individual to distinguish foreign material from "self" and neutralize and/or eliminate the foreign matter [13-14].

\section{Immune system}

The immune system is multi-layered, with defenses on numerous levels. The most primary is the skin, which is the first barrier to infection. Another one is a physiological condition such as $\mathrm{pH}$ and temperature provide living conditions for foreign organisms. Once pathogens enter the body, they deal with the innate immune and acquired or adaptive immune system. Both systems are composed of a mess of cells and molecules that interact in a complex manner to detect and eliminate pathogens. Both detection and elimination of pathogen depend upon chemical bonding: surfaces of immune system cells are engulfed with various receptors, some of them chemically bound with pathogens and some of which bind to other immune system cells or molecules to delegate the complex system of signaling that mediates the immune response [15-17] (See Fig. 1).

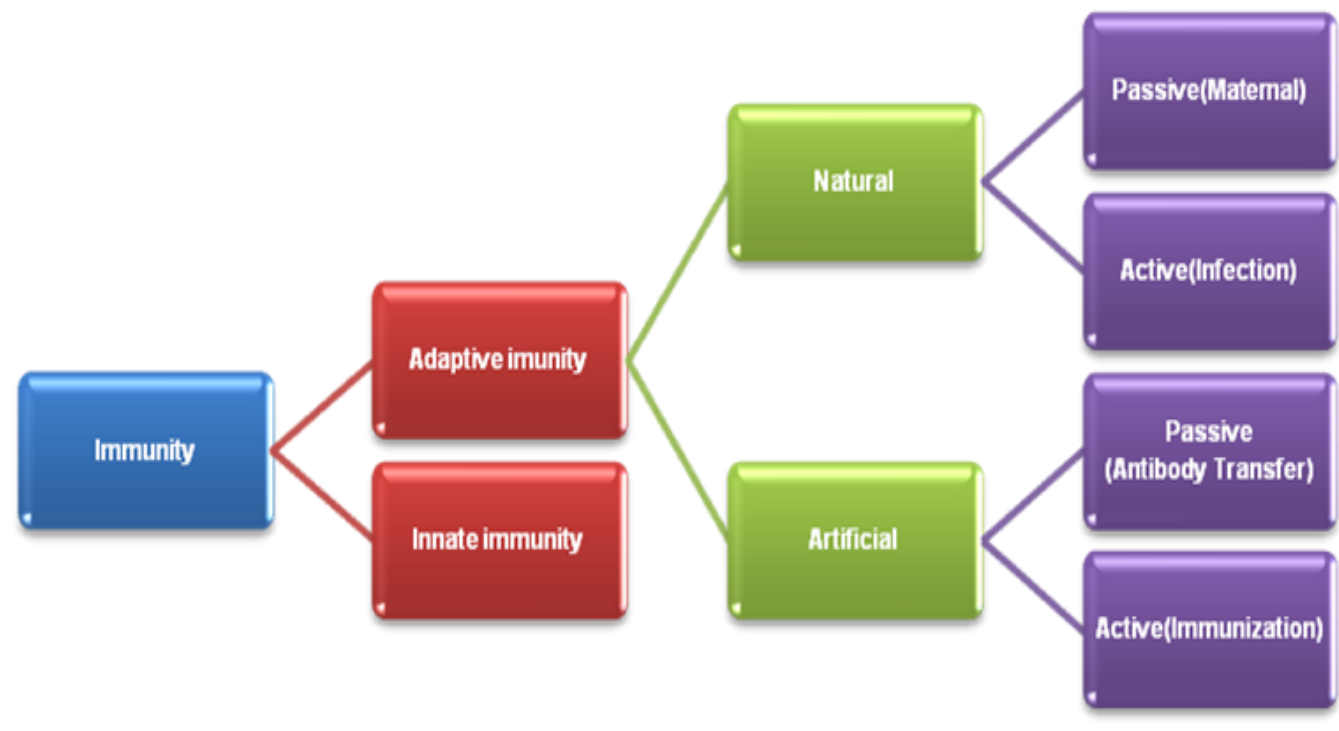

Figure 1 Types of immunity

\subsection{Innate immune system}

The term "innate" refers to that part of the system, with which we are born; that means, it doesn't change or adapt to specific pathogens like an adaptive system. The innate system gives a rapid first line of defense, to keep the early infection in check, giving the adaptive immune system time to build up a more specific response [18]. Innate immunity comprises primarily of a chemical response system called complement, and the endocytic and phagocytic systems, which involve roaming "scavenger" cells, such as macrophages, that detect and immerse extracellular molecules and materials, clearing the system of both debris and pathogens [19].

\subsection{Adaptive immune system}

The adaptive immune system adapts or "learns" to concede specific kinds of pathogens, and retains a "memory" of them for speeding up future responses. The learning occurs during a primary response to a kind of pathogen not encountered before by the system. The primary response is slow, often first only becoming apparent several days after the initial infection, and taking over three weeks to clear an infection. After the primary response clears an infection, the immune system keeps a memory of the kind of pathogen that caused the infection. Should the body be infected again by the equivalent kind of pathogen, the system doesn't need to re-learn to acknowledge the pathogens, because it remembers their specific appearance, and will mount a way more rapid and efficient secondary response [20]. 
The secondary response is often quick enough so that there are no clinical indications of a re-infection. Immune memory can confer protection up to the lifetime of the organism (measles is a good example in this regard). The adaptive immune system primarily consists of certain types of white blood cells, called lymphocytes, which circulate the body via the blood and lymph systems [21].

\section{Classification of immunomodulators}

The immune system may be a complex system that involves an interwoven network of biochemical mechanisms. The modulation of immune response by various agents to diminish the disease has been of interest for many years, to modulate and potentiate the weapons of your immune system keeping them in a highly prepared state for any threat it may confront with this balancing effect, all subsequent immune responses improve [22].

When your immune system is in this highly prepared state, the invading organisms do not have the time to build up force and strength before the immune system attack demolishes and/or weakens the invader. Immunomodulation is the process of improving immune response in a positive or negative approach by the administration of a drug or compound. Many proteins, amino acids, and natural compounds have shown a huge potential to manage immune responses including interferon- $\gamma$ (IFN- $\gamma$ ) and steroids. These substances, which can stimulate, suppress, or modify any of the immune systems, including both adaptive and innate arms of the immune response. Clinically, immunomodulators can be classified into the following three categories (See Fig. 2) [23-24].

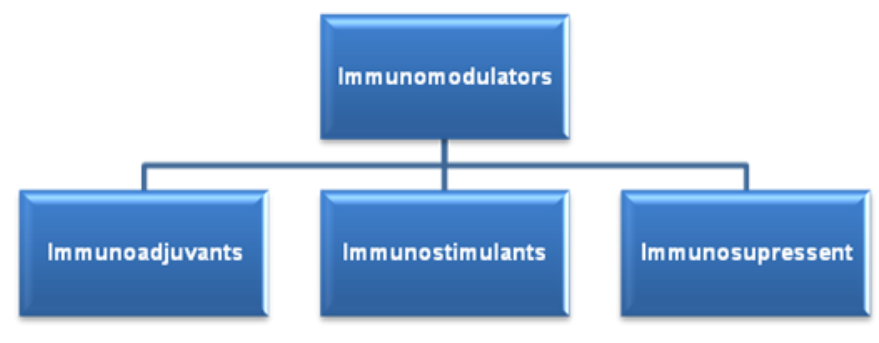

Figure 2 Classification of immunomodulators

\subsection{Immunoadjuvants}

These agents are used to increase the efficacy of vaccines and, therefore, could be considered specific immunostimulants. Immunoadjuvants act as true modulators of the immune response [25].

\subsection{Immunostimulants}

Immunostimulants are inherently non-specific as they are envisaged as enhancements to a body's resistance to infection. They can act through innate and adaptive immune responses. In healthy individuals, Immunostimulants are expected to serve as prophylactic and promoter agents by boosting the basic level of an immune response. In the individual with impairment of immune response, they are expected to act as immunotherapeutic agents [26].

\subsection{Immunosuppressants}

These are a structurally and functionally heterogeneous group of drugs, which are often concomitantly administered in combination regimens to treat various types of organ transplant rejection and autoimmune diseases [27].

\section{Methods for testing immunological factors}

The routine method for screening is to extract one ingredient and single distilled fraction from flavoring medicine and verify its bioactivity by the classic medical specialty means that. the total animal model is that the foremost classic medical specialty screening model, which is extraordinarily vital within the facet of drug analysis as a result of it will answer to the efficaciousness, facet impact, and toxicity of medicines as a full. Though this methodology is high value and low potency, it's still a primary due to drug discovery and analysis [28].

Many in-vitro and in-vivo strategies of medical specialty screening of healthful plants having immunomodulatory activity are listed below: 


\subsection{In-Vitro Methods}

(i)Inhibition of histamine release from mast cells, (ii) Mitogen induced lymphocyte proliferation, (iii) Inhibition of T cell proliferation, (iv) Chemiluminescence in macrophages PFC (plaque-forming colony) test in vitro, (v) Inhibition of dihydro-orotate dehydrogenase.

\subsection{In-Vivo Methods}

(i) Spontaneous autoimmune diseases in animals, (ii) Acute systemic anaphylaxis in rats, (iii) Anti-anaphylactic activity (Schultz-Dale reaction), (iv)Passive cutaneous anaphylaxis, (v) Arthus type immediate hypersensitivity, (vi)Delayed type hypersensitivity, (vii) Reversed passive Arthus reaction, (viii) Adjuvant arthritis in rats, (ix) Collagen type IIinduced arthritis in rats, (x) Proteoglycan-induced progressive polyarthritis in mice, (xi) Experimental autoimmune thyroiditis, (xii) Coxsackievirus B3-induced myocarditis, (xiii) Porcine cardiac myosin-induced autoimmune myocarditis in rats, (xiv) Experimental allergic encephalomyelitis, (xv) Acute graft versus host disease (GVHD) in rats, (xvi) Influence on SLE-like disorder in MRL/LPR mice, (xvii) Prevention of experimentally induced myasthenia gravis in rats, (xviii) Glomerulonephritis induced by anti-basement membrane antibody in rats, (xix) Auto-immune uveitis in rats, (xx) Inhibition of allogeneic transplant rejection.

\section{Pharmacology of immunomodulatory plants}

There is associate excessive would like for understanding plant-based drug medical specialty profile, administration, and dosage, since high doses tend to be immunological disorder and low doses of constant, tend to become immunostimulatory. Finally, it ought to be noted that the bulk of in vitro or in vivo models are not adequate or not straightforward enough to form certain that the same is commonly used as a drug. Several phytoconstituents from plants like polysaccharides are taken into consideration to be biological response modifiers and are reportable to bolster varied immune responses, like complement activation, a proliferation of lymphocytes, and stimulation of macrophages [29].

The immunopharmacological activities of phenolic are complicated and are still not fully understood. In-Vitro study does not forever settle for as true with observations in vivo study. Moreover, the consequences of various flavonoids could also be antagonistic; in some cases, they're an immunologicaldisorder, and in others, an immunostimulatory. Varied flavonoids a square measure seen to influence the performance of protein systems that a square measure critically concerned at intervals the immunologic response, and at intervals the generation of inflammatory processes, particularly within the transduction of cellular activation signals [30]. The Asteraceae family is the largest flowering plant having immunomodulatory activity. This family consists of about 900 genera and some 13,000 species [31]. Different plants having immunomodulatory activity are listed in Table 1.

Table 1 List of plants having immunomodulatory activity

\begin{tabular}{|c|c|c|c|}
\hline SN & Plant name & Family & Part use \\
\hline 1 & Boerhaavia diffusa & Nyctaginaceae & Root \\
\hline 2 & Curcuma longa & Zingiberaceae & Rhizome \\
\hline 3 & Rhododendron spiciferum & Ericaceae & Leaf \\
\hline 4 & Caesalpinia bonducella & Caesalpiniaceae & Whole plant \\
\hline 5 & Tinospora cordifolia & Menispermaceae & Whole plant \\
\hline 6 & Capparis zeylanica & Capparidaceae & Whole plant \\
\hline 7 & Luffa cylindrical & Cucurbitaceae & seed and fruit (bulb) \\
\hline 8 & Withania somnifera & Solanaceae & Whole plant \\
\hline 9 & Asparagus racemosus & Asparagaceae & Root \\
\hline 10 & Panax ginsengs & Araliaceae & Root \\
\hline 11 & Nelumbo nucifera & Nymphaeaceae & rhizome and seed \\
\hline 12 & Azadiracta indica & Meliaceae & Leaf \\
\hline 13 & Arnica montena & Compositae & Dried flowers head \\
\hline 14 & Calendula officinalis & Asteraceae & Flower \\
\hline 15 & Echinacea purpurea & Asteraceae & Flowering top \\
\hline 16 & Euphorbia tirucalli & Euphorbiaceae & Latex \\
\hline 17 & Ocimum sanctum & Lamiaceae & Leaf \\
\hline
\end{tabular}




\subsection{Boerhaavia diffussa}

Boerhaavia diffusa, (Punarnava; Family Nyctaginaceae), could also be a crawl weed found profusely each ever India. In Indian ancient medication, roots of this weed are used for the treatment of indigestion, jaundice, enlargement of spleen, abdominal pain, and associate degree as an anti-stress agent. Extraction of Boerhaavia diffusa in methane series, chloroform \& grain alcohol solvents, they isolated two different compounds, i.e. Bd-I (eupalitin-3-O-hDgalactopyranoside) and Bd-II (eupalitin) by Flash action. The methane series extract stifled considerably PHAstimulated proliferation of human peripheral blood mononucleate cells at the concentration of ten $\mu \mathrm{g} / \mathrm{ml}$, whereas chloroform and grain alcohol extract offer this activity at the concentration of fifty $\mu \mathrm{g} / \mathrm{ml}$. The suppression by Bd-I and $\mathrm{Bd}-\mathrm{II}$ is dose-dependent and ranged from 63 to 98 you have to attempt a five hundred $\mu \mathrm{g} / \mathrm{milliliter}$ to 7-14 attempt five $\mu \mathrm{g} / \mathrm{ml}$. On the opposite hand, the impact of chloroform extract on NK cell is eighty-four, the ethanolic extract is forty-eighth however, the Bd-I \& Bd-II is incredibly low [32].

\subsection{Curcuma longa}

Curcumin could be a main active constituent of Curcuma longa Linn belonging to the family Zingiberaceae. Asian nations are the largest country that produces turmeric (about ninetieth of the whole output of the world). Liliopsid genus is also a genus of concerning seventy species of stalk herbs distributed in South East Asia particularly China, Thailand, and Asian nation. Curcumin is employed for the treatment of medicine, antiarthritic, common colds \& coughs, jaundice [33]. The inhibition of IL-2 induced proliferation of cells was dose-dependent; since the increasing suppressive effect was observed at increasing concentration of curcumin from 6.25 to $25 \mathrm{~mol} / \mathrm{L}$. IL-2 induced proliferation of spleen cells was completely inhibited by curcumin at $25 \mathrm{~mol} / \mathrm{L}$ (See Table 2).

Table 2 Effect of curcumin on proliferation (p) of splenic lymphocytes

\begin{tabular}{|l|c|c|}
\hline Compound & Dose & Effect \\
\hline Curcumin & $6.25 \mu \mathrm{mol} / \mathrm{L}, 12.5 \mu \mathrm{mol} / \mathrm{L}, 25 \mu \mathrm{mol} / \mathrm{L}$ & $\mathrm{P}<0: 001, \mathrm{P}<0: 0001$, completely blocked \\
\hline
\end{tabular}

\subsection{Rhododendron spiciferum}

The plant Rhododendron spiciferum belonging to the Ericaceae. They will be widely used as a medicinal plant due to their active constituent's proanthocyanidin A-1 (PAA-1) is very used for health. Proanthocyanidin A-1 (PPA-1) is used attributable to the unconventional scavengers, anti-bacterial agents, and effective protein inhibitors. They conjointly exhibit the activity of vasodilators, anti-allergic, medicinal drug, cardio-protective, immune-stimulating, antiviral, and sex hormone activities [34-35].

\subsection{Caesalpinia bonducella}

Caesalpinia bonducella belonging to the Caesalpiniaceae. It's commonly referred to as Nata Karanja. It's anindigenous plant of India but also found to be Myanmar, Sri Lanka. The Caesalpinia prickly shrub, globular-shaped seeds with a smooth shining surface. The Seeds of those plants contain thick, brittle shells with a yellowish-white bitter fatty kernel. Caesalpini bonducella has employedthe shows following therapeutic activity like antipyretic, antidiuretic, anthelmintic and antibacterial, anti-anaphylactic and antidiarrheal, antiviral, antiasthmatic, antiamoebic, and anti-estrogenic.

Within the treatment of liver disorder and tumor, bonduc has been traditionally used. Extraction of Caesalpinia bonducella by the recent extraction process using ethanol as a solvent. This extract is employed for the activity of immunomodulatory within the mouse. The oral administration of Caesalpinia bonducella (ethanolic extract) withinthe mouse the effect of this is often given below (see Table 3) [36].

Table 3 Phagocytic response of extract in mouse

\begin{tabular}{|l|l|l|}
\hline Compound & Dose & Phagocytic index \\
\hline $\begin{array}{l}\text { Caesalpinia bonducella } \\
\text { extract(ethanolic) }\end{array}$ & $200 \mathrm{mg} / \mathrm{kg}$ & $4.72 \pm 0.66$, \\
\cline { 2 - 3 } & $300 \mathrm{mg} / \mathrm{kg}$ & $5.15 \pm 0.27$ \\
\cline { 2 - 3 } & $400 \mathrm{mg} / \mathrm{kg}$ & $6.19 \pm 0.45$ \\
\cline { 2 - 3 } & $500 \mathrm{mg} / \mathrm{kg}$ & $8.13 \pm 0.39$ \\
\hline
\end{tabular}




\subsection{Tinospora cordifolia}

Tinospora cordifolia belonging to the family of Menispermaceae. This is often a perennial climber distributed throughout the tropical Indian subcontinent. It's categorized as in Ayurveda and documented for its adaptogenic and immunomodulatory activity in fighting infection. The activity of this drug appears to flow from to alkaloid. The drug shows immunomodulatory activity. It's shown to be effective against various sorts of experimental induce infection [37].

In Tinospora cordifolia extract is referred to as a-d-glucan RR1. The recent extraction process employed for the extraction. In the extraction process the methanol, trichloracetic acid is employed as a solvent the compound RRA-1 is isolated from this extract by the tactic of chromatography \& lyophilization process [38].

They have according to that the result of Tinospora cordifolia extracts on leucocyte activation. The dose of the extract is one hundred $\mu \mathrm{g} / \mathrm{ml}$ can offer the result of leucocyte activation i.e. the activation of $\beta$-cells is thirty-ninth, T-cells one hundred and fifth, and NK cells is 331\% severally. Throughout this result the result of the extract on the NK cells is high; this might be vital|a crucial|a vital|a very important feature as a result of the NK cells square measure important effectors of innate immune system [39].

\subsection{Capparis zeylanica}

Capparis zeylanica, family Cappridaceae is typically mentioned as Indian caper, perhaps an ascent bush found throughout Republic of India and has been used as a 'Rasayana' drug at intervals the standard in Northern India; the leaves square measure wide used as counter-irritant, medicine and as a plaster, in swellings, boils, and piles. The varied Fig.6 Capparis zeylanica species of Capparis square measure helpful at intervals the treatment of cough, asthma, inflammation, fevers, and infectious disease and additionally helpful as poultice in urarthritis [40].

The result of immunomodulatory activity of ethanolic and water extracts of Capparis zeylanica leaves. This extract was used to the determination of cellular and body substance reaction victimization white blood corpuscle adhesion take a look at, somatic cell activity in sheep RBCs. The solvent used for the extraction fossil fuel ether, ethanol, and so the processes square measure hot extraction (Soxhlet). A big ( $\mathrm{P}<$ zero.05) increase within the in vitro white blood corpuscle adhesion to nylon fibers by water extract (at a dose of three hundred $\mathrm{mg} / \mathrm{kg}$, oral). However, ethanolic extract (150$300 \mathrm{mg} / \mathrm{kg}$ ) doesn't show any important increase in white blood corpuscle adhesion [41].

\subsection{Nelumbo nucifera}

Nelumbo nucifera is a plant belonging to the family of Nymphaeaceae. This plant could also be a well-known aquatic healthful plant that has been used as a typical medication in The Republic of India. The stalk extract of the sacred lotus, be employed for the activity of symptom, antidiarrheal, antimicrobial, diuretic, antipyretic, pharmacological medicine, medication. The seed of this plant is in addition, used for resultant activity as well as an anti-ischemic, inhibitor, hepatoprotective, antiproliferative, medication. The plant contains betulinic acid and hormone pentacyclic triterpenoid. Every extract of this plant is utilized for immunomodulatory activity [42].

The immunomodulatory effect of the plant extracts Nelumbonucifera, in Swiss albino mice. The extract (NNSE and NNRE) of rhizome and seeds was extracted with $70 \%$ ethanol by cold maceration process. It has been reported the activity is dose-dependent, i.e. the improvement of NBT (Nitro blue tetrazolium reduction test) a reduction was determined additional considerably at higher doses of each the extracts, three hundred mg/kg NNSE, P $<0.001$; NNREP $<0.01)$ and then that of their lower dose $100 \mathrm{mg} / \mathrm{kg}$ when compared to control $100 \mathrm{mg} / \mathrm{kg}(\mathrm{P}<0.01), 300 \mathrm{mg} / \mathrm{kg}(\mathrm{P}<$ 0.001 ) [43].

During their study, they were determined that adherence of neutrophils to the nylon fiber was augmented in each NNRE and NNSE treated teams as compared to the management and ended that hydroalcoholic extracts of a rootstock and seeds of a lotus showed stimulation of weapons system by modulating the medicine parameters and shows potential therapeutic edges of the plant components on immunomodulation [44].

\subsection{Allium sativum}

Allium sativum a crucial medicinal plant having immunomodulatory effects. Three proteins showing immunomodulatory were discrete from garlic by Q-Sepharose chromatography of $30 \mathrm{kD}$ ultrafiltrate of raw garlic extract of these proteins shows the mitogenic activity towards human peripheral blood lymphocytes, murine splenocytes, and thymocytes [45-46]. 
The extraction of garlic was prepared by blending the bulbs in phosphate buffer saline $(\mathrm{pH}, 7.4)$. Followed by ammonium sulfate precipitation and were isolated by ultra-filtration, and anion exchange chromatography using Q-Sepharose (High Performance) column taking unbuffered $20 \mathrm{~mm} \mathrm{1,3-diamino} \mathrm{propane} \mathrm{taken} \mathrm{in} \mathrm{1:10} \mathrm{ratio} \mathrm{(w/v),} \mathrm{Tris-} \mathrm{HCl}$ buffer, pH 8, and $\mathrm{NaCl}$. The eluted fractions were monitored by absorbance at $280 \mathrm{~nm}$ [47]. The richly present garlic ImPs, QR-1 and QR-2, identified in the present study agglutinins ASA II and ASA I, was found to be potent mutagenic activity having potential utility in therapeutic immunomodulation [48]. Many other plants show immunomodulation activities (See Table 4)<smiles>O=c1cc(-c2ccccc2)oc2ccccc12</smiles>

Flvanoids<smiles>O=c1ccc2ccccc2o1</smiles>

Caumarin

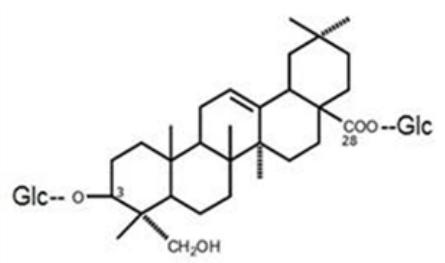

Saponin

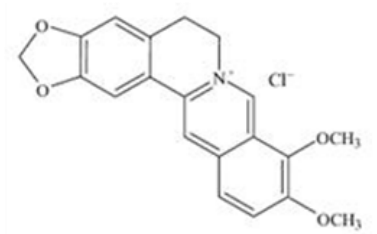

Berberine

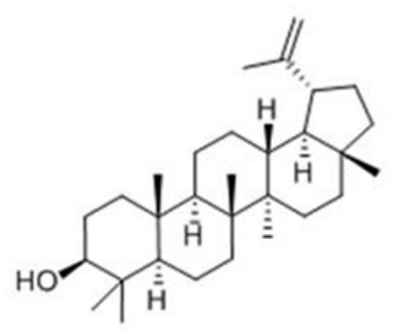

Lupeol<smiles>C=CCc1ccc(O)c(OC)c1</smiles>

Eugenol<smiles>O=C1c2ccccc2C(=O)c2ccccc21</smiles>

\section{Anthraquinone}<smiles>c1ccc2c(c1)[nH]c1ccccc12</smiles>

Carbozole Alkaloid

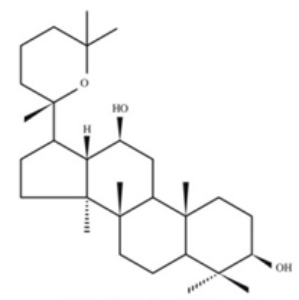

Panaxidiole<smiles>CC1=C(/C=C/C(C)=C/C=C/C(C)=C/CO)C(C)(C)CCC1</smiles>

Diterpine<smiles>Cc1cc(O)c2c(=O)c(O)c(-c3ccc(C)c(C)c3)oc2c1</smiles>

Flavonoids<smiles>Oc1cc(O)c2c(c1)O[C@H](c1ccc(O)c(O)c1)[C@H](O)C2</smiles>

Proanthocynidine

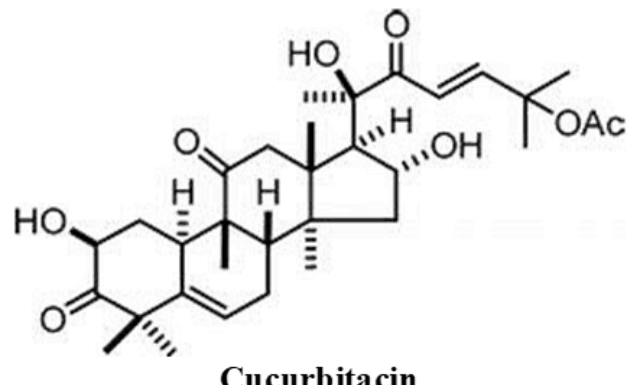

Cucurbitacin

Figure 3 Bioactive molecules showing immunomodulatory activity 
Table 4 A brief descriptions of common plant-derived immunomodulators

\begin{tabular}{|c|c|c|c|c|}
\hline $\begin{array}{c}\text { Botanical (Family) } \\
\text { name }\end{array}$ & $\begin{array}{l}\text { Ayurvedic/ } \\
\text { Common } \\
\text { name } \\
\end{array}$ & Part used & $\begin{array}{l}\text { Chemical } \\
\text { constituents }\end{array}$ & $\begin{array}{l}\text { Other biological } \\
\text { activities }\end{array}$ \\
\hline $\begin{array}{l}\text { Ocimum sanctum Linn. } \\
\text { (Labiateae) }\end{array}$ & Tulasi & Entire Plant & $\begin{array}{l}\text { Essential oils such as } \\
\text { eugenol, carvacrol }\end{array}$ & $\begin{array}{l}\text { Carminative, stomachic, } \\
\text { antispasmodic, } \\
\text { antiasthmatic, } \\
\text { hepatoprotective. }\end{array}$ \\
\hline $\begin{array}{l}\text { Morus alba Linn. } \\
\text { (Moraceae) }\end{array}$ & Brahmdaru & $\begin{array}{l}\text { Fruits, leaves, } \\
\text { bark, Fruits, }\end{array}$ & $\begin{array}{l}\text { Flavonoids, } \\
\text { anthocyanin's }\end{array}$ & $\begin{array}{l}\text { Expectorant, } \\
\text { hypocholesterolaemic, } \\
\text { diuretics. }\end{array}$ \\
\hline $\begin{array}{l}\text { Panax ginseng Wall. } \\
\text { (Araliaceae) }\end{array}$ & Ninjin & Fruits, root & $\begin{array}{l}\text { Saponins such as } \\
\text { ginsenosides, } \\
\text { panaxdiol, panaxtriole } \\
\text { and oleanolic acid }\end{array}$ & $\begin{array}{l}\text { Adaptogenic properties, } \\
\text { antiarrhythmics. }\end{array}$ \\
\hline $\begin{array}{l}\text { Achillea millefolium } C . \\
\text { Koch (Compositae) }\end{array}$ & Yarrow & Leaves & $\begin{array}{l}\text { Flavonoids, alkaloids, } \\
\text { polyacetylenes, } \\
\text { coumarins, triterpenes }\end{array}$ & $\begin{array}{l}\text { Anti-inflammatory, } \\
\text { antispasmodic, antipyretic, } \\
\text { diuretics. }\end{array}$ \\
\hline $\begin{array}{l}\text { Aloe vera Tourn. Ex } \\
\text { Linn. (Liliaceae) }\end{array}$ & Kumaari & Gel from leaves & $\begin{array}{l}\text { Anthraquinone } \\
\text { glycosides }\end{array}$ & $\begin{array}{l}\text { Purgative, emmenagogue, } \\
\text { emollient, anti- } \\
\text { inflammatory. }\end{array}$ \\
\hline $\begin{array}{l}\text { Andrographis } \\
\text { paniculata Nees } \\
\text { (Acanthaceae) }\end{array}$ & Kaalmegha & Leaves & Diterpenes & $\begin{array}{l}\text { Hepatoprotective, } \\
\text { antispasmodic, blood } \\
\text { purifier, febrifuge }\end{array}$ \\
\hline $\begin{array}{l}\text { Asparagus racemosus } \\
\text { Wild. (Liliaceae) }\end{array}$ & Shatavari & Roots & Saponins, sitosterols & $\begin{array}{l}\text { Ulcer healing agent, } \\
\text { nervine tonic, antigout }\end{array}$ \\
\hline $\begin{array}{l}\text { Murraya koenigii (L) } \\
\text { Spreng. (Rutaceae) }\end{array}$ & $\begin{array}{l}\text { Surabhini- } \\
\text { nimba }\end{array}$ & Leaves & $\begin{array}{l}\text { Coumarin, carbazole } \\
\text { alkaloids, glucoside }\end{array}$ & $\begin{array}{l}\text { Antifungal, insecticidal, } \\
\text { insecticidal. }\end{array}$ \\
\hline $\begin{array}{l}\text { Couroupita guianensis } \\
\text { Aubl. (Lecythidaceae) }\end{array}$ & Nagalinga & Fruits, flowers & $\begin{array}{l}\text { Steroids, flavonoids, } \\
\text { phenolics }\end{array}$ & Antifungal. \\
\hline $\begin{array}{l}\text { Tinospora cordifolia } \\
\text { Miers. } \\
\text { (Menispermiaceae) }\end{array}$ & $\begin{array}{l}\text { Amrita, } \\
\text { guduuchii }\end{array}$ & Entire herb & $\begin{array}{l}\text { Alkaloidal constituents } \\
\text { such as berberine, } \\
\text { tinosporic acid }\end{array}$ & $\begin{array}{l}\text { Hypoglycaemic agent, } \\
\text { antipyretic. }\end{array}$ \\
\hline $\begin{array}{l}\text { Lagenaria siceraria } \\
\text { Mol. (Cucurbitaceae) }\end{array}$ & Katu-tumbi & Leaves, fruit & $\begin{array}{l}\text { Cucurbitacin, beta- } \\
\text { glycosidase }\end{array}$ & Purgative, emetic. \\
\hline $\begin{array}{l}\text { Terminalia arjuna } \\
\text { Roxb. (Combretaceae) }\end{array}$ & Arjuna & Leaves, bark & Flavonoids, oligomeric & Cardiotonic, diuretic \\
\hline $\begin{array}{l}\text { Bauhinia variegata } \\
\text { Linn. } \\
\text { (Caesalpiniaceae) }\end{array}$ & Kaanchana & $\begin{array}{l}\text { Roots, bark, } \\
\text { buds }\end{array}$ & $\begin{array}{l}\text { Flavonoids, beta- } \\
\text { sitosterol, lupeol }\end{array}$ & Antifungal, astringent. \\
\hline $\begin{array}{l}\text { Urena lobata Linn. } \\
\text { (Malvaceae) }\end{array}$ & Naagabala & Roots, flowers & Flavanoids & $\begin{array}{l}\text { Diuretic, emollient, } \\
\text { antispasmodic. }\end{array}$ \\
\hline $\begin{array}{l}\text { Gymnema sylvestre } \\
\text { R.Br. (Asclepiadaceae) }\end{array}$ & Gurmaar & Leaves & Sapogenins & $\begin{array}{l}\text { Antidiabetic, diuretic, } \\
\text { antibilious. }\end{array}$ \\
\hline $\begin{array}{l}\text { Cordia superba Cham. } \\
\text { And C. rufescens A. DC. } \\
\text { (Boraginaceae) }\end{array}$ & Shleshmaataka & Leaf, fruit, bark & Alpha-amyrin & $\begin{array}{l}\text { Anti-inflammatory, } \\
\text { antimicrobial. }\end{array}$ \\
\hline $\begin{array}{l}\text { Picrorhiza } \\
\text { scrophulariiflora } \\
\text { Benth. } \\
\text { (Scrophulariaceae) }\end{array}$ & Kutki & Roots & $\begin{array}{l}\text { Iridoid glycosides, } \\
\text { amphicoside }\end{array}$ & Antioxidant. \\
\hline $\begin{array}{l}\text { Heracleum persicum } \\
\text { Desf. (Apiaceae }\end{array}$ & Golpar & Shurb & $\begin{array}{l}\text { Flavonoids, } \\
\text { furanocoumarins }\end{array}$ & Antimicrobial. \\
\hline $\begin{array}{l}\text { Cissampelos pareira } \\
\text { Linn. } \\
\text { (Menispermiaceae) }\end{array}$ & Paatha & Roots & Hayatine alkaloids & $\begin{array}{l}\text { Antipyretic, analgesic, } \\
\text { antilithic. }\end{array}$ \\
\hline
\end{tabular}


World Journal of Biology Pharmacy and Health Sciences, 2021, 06(02), 043-055

\begin{tabular}{|c|c|c|c|c|}
\hline $\begin{array}{l}\text { Abutilon indicum linn. } \\
\text { (Malvaceae) }\end{array}$ & Atibalaa & Whole plant & $\begin{array}{l}\text { Flavonoids, } \\
\text { triterpenoids }\end{array}$ & Diuretic, antibacterial. \\
\hline $\begin{array}{l}\text { Chlorophytum } \\
\text { borivilianum Sant. F } \\
\text { (Liliaceae) }\end{array}$ & Safed musli & Roots & Sapogenins & Antifungal. \\
\hline $\begin{array}{l}\text { Alternanthera tenella } \\
\text { Colla (Amaranthaceae) }\end{array}$ & Snow Ball & Herb & Flavonoids, triterpenes & $\begin{array}{l}\text { Antitumor, anti- } \\
\text { inflammatory. }\end{array}$ \\
\hline $\begin{array}{l}\text { Ganoderma lucidum } \\
\text { (Fr.) P. Karst. } \\
\text { (Polyporaceae) }\end{array}$ & $\begin{array}{l}\text { Reishi } \\
\text { mushroom }\end{array}$ & Whole plant & Flavonoids, triterpenes & Antioxidant. \\
\hline $\begin{array}{l}\text { Nyctanthes arbor- } \\
\text { tristis L. (Oleaceae) }\end{array}$ & Paarijaata & Leaf, seeds & Iridoid glucosides & $\begin{array}{l}\text { Anti-inflammatory, } \\
\text { antispasmodic }\end{array}$ \\
\hline $\begin{array}{l}\text { Actinidia macrosperma } \\
\text { C. F. Liang } \\
\text { (Actinidiaceae) }\end{array}$ & Actinidia & Fruits & Alkaloids, saponins & Antileprotic. \\
\hline $\begin{array}{l}\text { Acacia catechu Willd. } \\
\text { (Leguminosae) }\end{array}$ & Khadira & Leaf & Flavonoids, quercetin & Hypoglycaemic, astringent \\
\hline $\begin{array}{l}\text { Boswellia spp. } \\
\text { (Burseraceae) }\end{array}$ & Shallaki & Gum resin & Triterpenes, ursanes & Hypoglycaemic. \\
\hline $\begin{array}{l}\text { Hibiscus rosa sinensis } \\
\text { Linn. (Malvaceae) }\end{array}$ & Japaa & Flowers & Cyclopropanoids & $\begin{array}{l}\text { Antidiarrheal, anti- } \\
\text { inflammatory. }\end{array}$ \\
\hline $\begin{array}{l}\text { Cleome gynandra Linn. } \\
\text { (Capperdiceae) }\end{array}$ & Tilaparni & Leaf, seeds, rots & $\begin{array}{l}\text { Hexacosanol, } \\
\text { kaempferol }\end{array}$ & Anti-inflammatory. \\
\hline $\begin{array}{l}\text { Hyptis suaveolens (L.) } \\
\text { Poit. (Lamaceae) }\end{array}$ & Tumbaaka & Leaf, flowers & Lupeol, beta-sitosterol & $\begin{array}{l}\text { Carminative, } \\
\text { antispasmodic. }\end{array}$ \\
\hline $\begin{array}{l}\text { Randia dumetorum } \\
\text { Lamk. (Rubiaceae) }\end{array}$ & Madana & Fruits & Saponins, triterpenes & Chlorosis, antiarthritic. \\
\hline $\begin{array}{l}\text { Allium hirtifolium } \\
\text { Boiss. (Alliaceae) }\end{array}$ & Persian shallot & Herb & $\begin{array}{l}\text { Thiosulfinates, } \\
\text { flavonoids }\end{array}$ & $\begin{array}{l}\text { Antirheumatic, anti- } \\
\text { inflammatory. }\end{array}$ \\
\hline $\begin{array}{l}\text { Acanthopanax } \\
\text { sessiliflorus (Rupr. \& } \\
\text { Maxim.) (Araliaceae) }\end{array}$ & Prickly spine & $\begin{array}{l}\text { Shoots and } \\
\text { roots }\end{array}$ & Biopolymers & $\begin{array}{l}\text { Lymphoproliferative } \\
\text { activity. }\end{array}$ \\
\hline $\begin{array}{l}\text { Agelas mauritianus } \\
\text { (Porifera) }\end{array}$ & Agelas & Sponge & $\begin{array}{l}\text { Glycolipid } \\
\text { galactosylceramide) }\end{array}$ & Phagocytotic activity. \\
\hline $\begin{array}{l}\text { Aphanothece } \\
\text { halophytica } \\
\text { (Chroococcales) }\end{array}$ & & Cyanobacterium & Exopolysaccharide & Inhibits influenza virus. \\
\hline $\begin{array}{l}\text { Apium graveolens Linn. } \\
\text { (Apiaceae) }\end{array}$ & Celery Seeds & Leaves, seeds & Flavonoids, coumarins & Anti-inflammatory. \\
\hline $\begin{array}{l}\text { Genus Ardisia } \\
\text { (Myrsinaceae) }\end{array}$ & Marlberry & $\begin{array}{l}\text { Shrub, } \\
\text { Branches, and } \\
\text { leaves }\end{array}$ & $\begin{array}{l}\text { Peptides, saponins, } \\
\text { Isocoumarins, } \\
\text { quinones, and } \\
\text { alkylphenols }\end{array}$ & $\begin{array}{l}\text { The antimetastatic drug, } \\
\text { anti-HIV property. }\end{array}$ \\
\hline $\begin{array}{l}\text { Genus Aristolochia } \\
\text { (Aristolochiaceae) }\end{array}$ & Pipevine & Leaves & Aristolochic acid & $\begin{array}{l}\text { Antiangiogenic, employed } \\
\text { in prostate cancer. }\end{array}$ \\
\hline $\begin{array}{l}\text { Artemisia annua Linn. } \\
\text { (Compositea) }\end{array}$ & Wormwood & Herb & Artemisinin & Immunosuppressive. \\
\hline $\begin{array}{l}\text { Genus Aspergillus } \\
\text { (Trichocomaceae) }\end{array}$ & Aspergillus & Fungus & Polyene, triazole & Antifungals. \\
\hline
\end{tabular}




\begin{tabular}{|l|l|l|l|l|}
\hline $\begin{array}{l}\text { Botryllus schlosseri } \\
\text { (Botryllidae) }\end{array}$ & Botryllus & Tunicates & Cytokines & $\begin{array}{l}\text { Antioxidant, antiviral, } \\
\text { antimicrobial and } \\
\text { antitumoral. }\end{array}$ \\
\hline $\begin{array}{l}\text { Bidens pilosa L. } \\
\text { (Asteraceae) }\end{array}$ & Beggar-ticks & Flowers, leaves & Polyacetylenes & $\begin{array}{l}\text { Anti-inflammatory, } \\
\text { immunosuppressive. }\end{array}$ \\
\hline $\begin{array}{l}\text { Boerhaavia diffusa } \\
\text { (Nyctaginaceae) }\end{array}$ & Punarnava & Herb & Alkaloid & Immunostimulatory. \\
\hline $\begin{array}{l}\text { Bugula neritina L. } \\
\text { (Bugulida) }\end{array}$ & $\begin{array}{l}\text { Brown } \\
\text { bryozoans }\end{array}$ & $\begin{array}{l}\text { Marine } \\
\text { invertebrates }\end{array}$ & Macrocyclic lactones & Immunomodulator. \\
\hline $\begin{array}{l}\text { Byrsonima crassa Nied. } \\
\text { (Malpighiaceae) }\end{array}$ & Byrsonima & Leaves & $\begin{array}{l}\text { Flavonoids, tannins, } \\
\text { terpenes }\end{array}$ & Antimicrobial, antioxidant. \\
\hline $\begin{array}{l}\text { Calendula Officinalis L. } \\
\text { (Asteraceae) }\end{array}$ & $\begin{array}{l}\text { Garden } \\
\text { Marigold }\end{array}$ & Flowers & $\begin{array}{l}\text { Polysaccharides, } \\
\text { proteins, fatty acids, } \\
\text { carotenoids, flavonoids, } \\
\text { triterpenoids }\end{array}$ & $\begin{array}{l}\text { Antitumor antiviral } \\
\text { activity, anti-HIV } \\
\text { properties. }\end{array}$ \\
\hline $\begin{array}{l}\text { Camellia sinensis L. } \\
\text { (Theaceae) }\end{array}$ & Tea & Leaves & $\begin{array}{l}\text { Epigallocatechingallate, } \\
\text { quercetin, gallicacid }\end{array}$ & $\begin{array}{l}\text { Anticancer activity, lipid- } \\
\text { lowering activity, } \\
\text { anticataract activity, } \\
\text { hepatoprotective and } \\
\text { antioxidant. }\end{array}$ \\
\hline $\begin{array}{l}\text { Cannabis sativa } \\
\text { (Cannabaceae) }\end{array}$ & Common hemp & Leaves & Cannabinoids & Immunomodulatory. \\
\hline $\begin{array}{l}\text { Carpobrotus edulis L. } \\
\text { (Aizoaceae) }\end{array}$ & Fig Marigold & Flowers, fruit & Alkaloids & Triterpenoid saponins \\
\hline $\begin{array}{l}\text { Centella asiatica Linn. } \\
\text { (Umbelliferae) }\end{array}$ & Brahmi & Herb & Immunomodulator. \\
\hline
\end{tabular}

\section{Conclusion}

From this discussion, it's evident that many medicinal plants exert an immunomodulatory effect in experimental models at a specific dose. Different types of in vivo and in vitro screening methods are employed in determining their pharmacological activity. Some medicinal plants may stimulate the system like Ocimum sanctum, Tinospora cordifolia and a few of them may suppress the immune responses (Eg. Alternanthera tenella). The review also reveals an update of the present immunomodulator plants and their pharmacological aspects. Thus successful results are achieved by following an appropriate screening approach.

\section{Compliance with ethical standards}

\section{Acknowledgments}

Authors are thankful to Shri. Yogendraji Gode (President) and Dr. Yogeshji Gode (Secretary), IBSS's Dr. Rajendra Gode Institute of Pharmacy, Amravati and Dr. Rajendra Gode College of Pharmacy, Amravati, Maharashtra (India) for providing necessary facility to undertake this work.

\section{Disclosure of conflict of interest}

The author declares no conflict of interest. 


\section{References}

[1] Cascella M, Rajnik M, Aleem A, Dulebohn S, Di Napoli R. Features, evaluation, and treatment of coronavirus (COVID-19). StatPearls. 2021 Apr 20.

[2] Ashour HM, Elkhatib WF, Rahman MM, Elshabrawy HA. Insights into the Recent 2019 Novel Coronavirus (SARSCoV-2) in Light of Past Human Coronavirus Outbreaks. Pathogens. 4 Mar 2020; 9(3): 186.

[3] Rastogi S, Pandey DN, Singh RH. COVID-19 pandemic: A pragmatic plan for Ayurveda intervention. J Ayurveda Integr Med. 23 Apr2020; S0975-9476(20)30019.

[4] Manmode R, Manwar J, Vohra M, Padgilwar S, Bhajipale N. Effect of Preparation Method on Antioxidant Activity of Ayurvedic Formulation Kumaryasava. J Homeop Ayurv Med. 2012; 1:114.

[5] Manwar JV, Mahadik KR, Sathiyanarayanan L, Paradkar AR, Patil SV. Comparative antioxidant potential of Withania somnifera based herbal formulation prepared by traditional and non-traditional fermentation processes. Integr Med Res. 2013; 2: 56-61.

[6] Padgilwar S, Manwar J, Vohra M, Banginwar Y. Traditional Uses, Phytochemistry and Pharmacology of Oroxylum Indicum: A Review. International Journal of Pharmaceutical and Phytopharmacological Research.2014; 3(6): 483-486.

[7] Malode GP, et al. Phytochemistry, pharmacology and botanical aspects of Murraya Koenigii in the search for molecules with bioactive potential - A review. GSC Advanced Research and Reviews. 2021; 06(03): $143-155$.

[8] Gudalwar BR, et al. Allium sativum, a potential phytopharmacological source of natural medicine for better health. GSC Advanced Research and Reviews. 2021; 06(03):220-232.

[9] Wadekar AB, et al. Morphology, phytochemistry and pharmacological aspects of Carica papaya, an review. GSC Biological and Pharmaceutical Sciences. 2020; 14(03):234-248.

[10] Badukale NA, et al. Phytochemistry, pharmacology and botanical aspects of Madhuca indica: A review. Journal of Pharmacognosy and Phytochemistry. 2021; 10(2): 1280-1286.

[11] Tiwari R, Latheef SK, Ahmed I, Iqbal HMN, Bule MH, Dhama K, Samad HA, Karthik K, Alagawany M, El-Hack MEA, Yatoo MI, Farag MR. Herbal Immunomodulators - A Remedial Panacea for Designing and Developing Effective Drugs and Medicines: Current Scenario and Future Prospects. Curr Drug Metab. 2018;19(3):264-301.

[12] Mahima, Rahal A, Deb R, Latheef SK, Abdul Samad H, Tiwari R, Verma AK, Kumar A, Dhama K. Immunomodulatory and therapeutic potentials of herbal, traditional/indigenous and ethnoveterinary medicines. Pak J Biol Sci. 15 Aug 2012; 15(16): 754-74.

[13] Brestoff JR, Artis D. Immune regulation of metabolic homeostasis in health and disease. Cell. 2015;161(1):146160.

[14] Kumari M, Heeren J, Scheja L. Regulation of immunometabolism in adipose tissue. Semin Immunopathol. Feb 2018;40(2):189-202.

[15] Parkin J, Cohen B. An overview of the immune system. Lancet. 2 Jun 2001; 357(9270): 1777-89.

[16] Sattler S. The Role of the Immune System Beyond the Fight Against Infection. Adv Exp Med Biol. 2017; 1003: 314.

[17] McComb S, Thiriot A, Akache B, Krishnan L, Stark F. Introduction to the Immune System. Methods Mol Biol. 2019;2024:1-24.

[18] Yatim KM, Lakkis FG. A brief journey through the immune system. Clin J Am Soc Nephrol. 2015;10(7):1274-81.

[19] Weiskopf D, Weinberger B, Grubeck-Loebenstein B. The aging of the immune system. Transpl Int. Nov 2009;22(11):1041-50.

[20] Cooper MD, Alder MN. The evolution of adaptive immune systems. Cell. 24 Feb 2006; 124(4): 815-22.

[21] Liu YM, Luo J, Bennett C. Adaptive immunity: Based on the dual recognition responses of $\alpha \beta T$ cells. Self Nonself. 2010;1(1):62-66.

[22] Aristizábal B, González Á. Innate immune system. In: Anaya JM, Shoenfeld Y, Rojas-Villarraga A, et al., editors. Autoimmunity: From Bench to Bedside [Internet]. Bogota (Colombia): El Rosario University Press. 18 Jul 2013 ; 2. 
[23] Alberts B, Johnson A, Lewis J, et al. Molecular Biology of the Cell. 4th edition. New York: Garland Science. Innate Immunity. 2020.

[24] McComb S, Thiriot A, Akache B, Krishnan L, Stark F. Introduction to the Immune System. Methods Mol Biol. 2019; 2024: 1-24.

[25] Shah RR, Hassett KJ, Brito LA. Overview of Vaccine Adjuvants: Introduction, History, and Current Status. Methods Mol Biol. 2017;1494:1-13.

[26] Hadden JW. Immunostimulants. Immunol Today. 1993;14(6):275-80. Erratum in: Immunol Today. Apr 2008; 29(4): 149.

[27] Derek E, Dhanireddy K. Immunosuppression. Curr Opin Organ Transplant. Dec 2012; 17(6): 616-8.

[28] Braddock M. Methods for Testing Immunological Factors. Drug Discovery and Evaluation: Pharmacological Assays. 2015;2091-2203.

[29] Schepetkin IA, Quinn MT. Botanical polysaccharides: macrophage immunomodulation and therapeutic potential. Int Immunopharmacol. Mar 2006;6(3): 317-33.

[30] Kislova LK. Immuno-modulating properties of medicinal plant preparation from Echinacea purpurea. Antibiot Khimioter. 2003; 48(9): 41-2.

[31] Tiwari U, Rastogi B, Singh P, Saraf DK, Vyas SP. Immunomodulatory effects of aqueous extract of Tridax procumbens in experimental animals. J Ethnopharmacol.May 2004;92(1):113-9.

[32] Pandeya R, et al. A Research article on Immunosuppressive properties of flavonoids isolated from Boerhaavia diffusa Linn. International immunopharmacology. 2005; 5: 541-553.

[33] Chainani-Wu N. Safety and anti-inflammatory activity of curcumin: a component of tumeric (Curcuma longa). J Altern Complement Med.Feb 2003;9(1): 161-8.

[34] Liu YZ, Cao YG, Ye JQ, Wang WG, Song KJ, Wang XL, Wang CH, Li RT, Deng XM. Immunomodulatory effects of proanthocyanidin A-1 derived in vitro from Rhododendron spiciferum. Fitoterapia. Mar 2010;81(2):108-14.

[35] Liu Y, Wang C, Dong X, Cheng D, Zhou T. Immunomodulatory effects of epicatechin- $(2 \beta \rightarrow 0 \rightarrow 7$, 4 $\beta \rightarrow 8)$-entepicatechin isolated from Rhododendron spiciferum in vitro. Immunopharmacol Immunotoxicol. 2015; 37(6): 527-34.

[36] Shukla S, Mehta A, John J, Mehta P, Vyas SP, Shukla S. Immunomodulatory activities of the ethanolic extract of Caesalpinia bonducella seeds. J Ethnopharmacol. 7 Sep 2009;125(2):252-6.

[37] Singh D, Chaudhuri PK. Chemistry and Pharmacology of Tinospora cordifolia. Nat Prod Commun. Feb 2017;12(2):299-308.

[38] Upadhyay AK, Kumar K, Kumar A, Mishra HS. Tinospora cordifolia (Willd.) Hook. f. and Thoms. (Guduchi) validation of the Ayurvedic pharmacology through experimental and clinical studies. Int J Ayurveda Res. Apr 2010; 1(2): 112-21.

[39] Kumar P, Kamle M, Mahato DK, Bora H, Sharma B, Rasane P, Bajpai VK. Tinospora cordifolia (Giloy): Phytochemistry, Ethnopharmacology, Clinical Application and Conservation Strategies. Curr Pharm Biotechnol. 2020; 21(12): 1165-1175.

[40] Sini KR, Sinha BN, Rajasekaran A. Protective Effects of Capparis zeylanica Linn. Leaf Extract on Gastric Lesions in Experimental Animals. Avicenna J Med Biotechnol. Jan 2011; 3(1): 31-5.

[41] Ghule BV, Murugananthan G, Nakhat PD, Yeole PG. Immunostimulant effects of Capparis zeylanica Linn. leaves. J Ethnopharmacol. 24 Nov 2006;108(2):311-5.

[42] Tungmunnithum D, Pinthong D, Hano C. Flavonoids from Nelumbo nucifera Gaertn., a Medicinal Plant: Uses in Traditional Medicine, Phytochemistry and Pharmacological Activities. Medicines (Basel). 23 Nov 2018;5(4):127.

[43] Mukherjee PK, Mukherjee D, Maji AK, Rai S, Heinrich M. The sacred lotus (Nelumbo nucifera) - phytochemical and therapeutic profile. J Pharm Pharmacol. Apr 2009;61(4):407-22.

[44] Mukherjee D, Khatua TN, Venkatesh P, Saha BP, Mukherjee PK. Immunomodulatory potential of rhizome and seed extracts of Nelumbo nucifera Gaertn. J Ethnopharmacol. 24 Mar 2010 ;128(2):490-4.

[45] Adaki S, Adaki R, Shah K, Karagir A. Garlic: Review of literature. Indian J Cancer. 2014; 51: 577-81. 
World Journal of Biology Pharmacy and Health Sciences, 2021, 06(02), 043-055

[46] Rivlin RS. Historical perspective on the use of garlic. J Nutr. 2001; 131: 951S-954S.

[47] Onuora Chidinma, Ofili C Timothy, Salawu Samuel, Elimian Isaac and Shehu Hauwa. Therapeutic Effects of Garlic: A Review. Sci J Biol \& Life Sci. 2019; 1(1).

[48] Bayan L, Koulivand PH, Gorji A. Garlic: A Review of Potential Therapeutic Effects. Avicenna Journal of Phytomedicine. 2014; 4(1): 1-14. 